\title{
Analysis of Forest Governance in Far-Western Terai Region of Nepal $^{1}$
}

\section{Keshab Raj Pant}

\begin{abstract}
To explore the status of governance in Community Forestry (CF) user groups (CFUGs) in Far- Western Terai region of Nepal, six community forest user groups were selected from Kailali and Kanchanpur districts considering ethnicity, gender, size of households and accessibility. UNESCAP's eight criteria of good governance and their respective local indicators were employed to explore the governance status of CF. Direct observation; key informant's survey, focus group discussion and household interview with questionnaire format were used to collect the primary data where secondary data were collected from operational plan of CFUGs and other published literatures. Simple mathematical procedures were used to analyze the data. The study findings show that overall governance level is very good in women managed CFs then mixed managed CFs as well as the relationships of governance with economic activities and ethnic composition of community. This study also shows that women managed CFs is more transparent and responsive to users. Which shows that the fairness in responsibility in woman managed CF is very good and their executive committee was more responsive to their users and disadvantaged groups.
\end{abstract}

Keywords: Accountability; Community Forestry; Gender; Transparency

\section{Background}

The concepts of governance have been explained by different scholars, governance experts, development thinkers, social scientists, economists and development institutions in specific contexts. United Nations Economic and Social Commission for Asia and Pacific

\footnotetext{
${ }^{1}$ Cite this article as: Pant, K. R. (2021). Contemporary Research: An Interdisciplinary Academic Journal, vol. 5 (1) DOI: https://doi.org/10.3126/craiaj.v5i1.40481

Keshab Raj Pant, Kailali Multiple Campus, Kailali, Nepal; Email: pantkr89@gmail.com Article history: Received on June 5; Accepted on September 21; Published on October 21

Peer reviewed under the authority of CRAIAJ, academic journal of Ghodaghodi Multiple Campus, Kailali, Nepal, with ISSN 2717-4611 (Print) and ISSN 2717-462X (Online).

(C) 2021CRAIAJ
}

Full text of this article can be downloaded fromwww.craiaj.comand www.nepjol.info 
(UNESCAP) defines governance as the process of decision- making and the process in which decisions are implemented or not implemented (Sheng, 2009). Where, World Bank's (WB) Poverty Reduction Strategy Paper (PRSP) defines governance as the manner in which power is exercised in the management of a country's economic and social resources. The Asian Development Bank (ADB) defines governance as a process referring to the manner in which power is exercised in the management of the affairs of a nation, and its relations with other nations (Quibria, 2015). Graham et al. (2003) refer that governance is about the interactions among structures, processes, and traditions that determine how power and responsibilities are exercised, how decisions are taken and how citizens or other stakeholders have their views.

There are numbers of definitions used for forest governance. Higman (2013), states that forest governance is all about the quality of decision-making process rather than other political and governmental structures. These authors further explain good forest governance as it enhances and encourages the sustainable forest management. Kishor and Rosenbaum (2012) argue that forest governance is the set of principles which includes norms, processes, people, institutions, instruments and organizations that control how local people interact with forest resources. They further state that, good governance in Community Forest (CF) level is associated with inclusive participation of related stakeholders, accountability of actors and decision-makers with transparency in decisionmaking, proper enforcement of rules of law, effective and efficient management of natural, financial and human resources including fair and equitable allocations of resources and benefits as well as predictability of total system.

With wide definitions of forest governance, it is very challenging to include all and cover all aspects. Therefore, in this context this study define good forest governance as the framework in which all stakeholders have equal opportunities to participate in decisionmaking and benefit sharing mechanisms of their forest resources. It is all about the responsible exercise of all different types of powers in order to meet the objectives of the institutions. From the above definitions of governance, for this research the definition of governance is all about who decides and what objects are, how these decisions are taken, who holds power, authority and responsibility, who is accountable for and what means are applied to manage them with which law. This definition of good forest governance however would not be relevant in all aspects because forest policy, norms, and regulations 
may differ in different situations. Based on the definitions and concepts of governance by different scholars, joint effort is required from all sectors to maintain the good governance in forestry sectors.

Nepal is a pioneer state involved in the introducing of community forestry (CF) (Shin, 2013). Community forest is a part of national forests handed over to the local community users' group for its development, conservation and utilization for collective benefits (Gautama, 2009). The concept of CF was introduced in Nepal in the 1970s. The community forestry is an institutional innovation of empowering local communities in managing forest resources for their benefit in co-ordination with the government. The period from 1978s onward can considered as the CF phase, which began with a review of the forestry sector and the relationship between the population and the natural resources of Nepal. Community forestry program implemented in Nepal is guided by Forest Act of 1993 and the Forest guideline 2008, which is latest version of Forest Rules of 1995. In 1978, the government of Nepal introduced legislation and gave local people responsibility for managing the CF (Pandey et. al, 2015). After that, local people making Community Forest User Groups (CFUGs) and which allows the benefit distribution too locally and rights to control the Forest locally.

CFUGs are working as independent entities at local level in CF. The formulation of the National Forestry Plan in 1976 provided a policy base for initiating forestry development work in the hills of Nepal and it was a bold shift in policy towards participatory forestry. The Master Plan for the Forestry Sector (MPFS) further stressed that participation of local communities in decision-making and benefit sharing was essential for the conservation of forest management. The Forest Act of 1993 and made provision that the use and management of community forestry is done independently by the CFUGs, the marketing of timber and other forest products being without any doubt a management task. Government of Nepal implement forest act 2076 to manage forest resources in federal system. About 1.45 million households or 35 percent of the population of Nepal is involved in CF management program. To date 19,361 CFUGs have been formed of which are composed of $\mathbf{1 0 7 2}$ women only committee members. A total of 18,13,478 hectares of national forest have been handed over as community forests and $\mathbf{2 4 , 6 1 , 5 4 9}$ households have benefited (DoF, 2017). Based on the definitions and concepts of governance by 
different scholars for forestry sector make clear that joint efforts is required from all sectors to maintain the good governance in forestry sectors.

Community forest is a part of national forest handed over to the local community users' group for its development, conservation and utilization for collective benefits (Gautam, 2009). Nepal is a pioneer state involved in introducing community forestry (CF). It is a highly successful participatory program of Nepal in forestry sector. However, the problem of governance and CF management practices emerged as second generation issues in this sector. There are questions of governance, gender equality, equity and women's access to decision- making that needed further studies within community forestry. And to make CF more democratic and successful the answer of these questions are necessary to investigate (Gautam, 2009). There are many issues in CF like unequal representation in decision-making, lack of transparency and inequity in benefit sharing (Dorgali et al., 2004) which are necessary to solve for sustainable forest management. In general, governance includes all methods, both good and bad, exists in society to distribute power and manage all public resources and problems in response to the critical needs of the society (Gentle et al., 2007). Women face more significant obstacles than their men to make active participation in decision making related to forest sector of their community (Evans, K., et al., 2016). Women in India and Nepal face multiple obstacles to participate in public areas (Agrawal., 2001). When there is poor governance in CFUGs, the major decisions and economic activities are less transparent to general users. Majority of literatures claimed that, the elite group captures is one of the key challenge for good governance in CF management in Nepal (Dhananjaya.et.al, 2014; Thakur, 2011; Chaudhary, 2016). In this context this research seeks to examine the status of good governance indicators in different CFUGs located at Kailali and Kanchanpur districts of Far-western Terai region of Nepal.

\section{Research Methodology}

\section{Study Area}

For this study, Kailali and Kanchanpur two districts located in Far- Western Terai region of Nepal were purposively selected. Community Forest program has been intensively implemented in the area for more than two decades. Additionally, recommendation from Terai Arc Landscape (TAL)- Bottle neck and restoration project office Kohalpur, Bankey was considered while selecting the specific sites and CFUGs. However CFUGs with average management condition were selected based on the 
following five criteria (i) local peoples' dependency on forest and management system, (ii) heterogeneous compositions of users in terms of economic class, gender and caste, (iii) CF supported by TAL-Nepal, (iv) Forest Operational Plan (OP) were recently made and revised and (v) Socially complex site, but comparatively secure and easy to conduct field works. Depends on the above criteria six CFUGs namely Jankalyan CFUG, Chetana Mahila CFUG, Bandevi CFUG, Sahara CFUG, Shiva CFUG and Mohana CFUG were selected for study. Table 1 below shows the general characteristics of selected six CFUGs of Far-Western Terai of Nepal.

Table 1:General characteristics of selected six CFUGs

\begin{tabular}{|l|l|l|l|l|l|}
\hline SN & Name of CFUG & Address & $\begin{array}{l}\text { Hand } \\
\text { over } \\
(\text { B.S })\end{array}$ & $\begin{array}{l}\text { Area } \\
(\mathrm{Ha})\end{array}$ & $\begin{array}{l}\text { Number of } \\
\text { households }\end{array}$ \\
\hline 1 & Jankalyan CFUG & $\begin{array}{l}\text { Lamki-Chuha 02, } \\
\text { Kailali }\end{array}$ & 2063 & 246.0 & 1498 \\
\hline 2 & $\begin{array}{l}\text { Chetana Mahila } \\
\text { CFUG }\end{array}$ & Godavari 09, Kailali & 2062 & 50.31 & 75 \\
\hline 3 & Bandevi CFUG & $\begin{array}{l}\text { Krishnapur 07, } \\
\text { Kanchanpur }\end{array}$ & 2072 & 149.0 & 302 \\
\hline 4 & Sahara CFUG & Ratanpur 07, Kailali & 2067 & 50.09 & 103 \\
\hline 5 & Shiva CFUG & Kailari 07, Kailali & 2066 & 29.09 & 45 \\
\hline 6 & Mohana CFUG & Kailari 07, Kailali & 2068 & 28.55 & 65 \\
\hline
\end{tabular}

\section{Research Design}

This research is carried out with descriptive as well as explanatory field based research approach. The household was considered as the lowest unit of sampling. To calculate the appropriate sample, mathematical formula was used with ninety- five percent level of confidence. To minimize error due to heterogeneity of community and representation from each group stratified random sampling method was applied for field survey. The basis for stratification was ethnicity, caste, economic well being class and physical location. From the selected six CFUGs, 325 households were selected for the study on the basis of ethnicity, gender, and well-being ranking. Key interviewed, household survey and focus group discussion were taken. Questionnaires and checklists were prepared and tested as test-retest method before apply for data collection. Both

Full text of this article can be downloaded fromwww.craiaj.comand www.nepjol.info 
quantitative and qualitative data were collected for the study. Matrix ranking was used to get pre-hand evaluation of existing governance capacity of the CFUGs. UNESCAP's eight criteria of good governance were adopted and local indicators were developed and employed in arrangement with local people to explore the governance status of CF.

\section{Selection of Criteria and Indicators}

Severalpublished and unpublished literatures were reviewed for this study. Based on literature review, UNESCAP's eight criteria of good governance were taken in to account. Local indicators were developed and employed to study the governance of CF. Detailed about the eight criteria and their respective local indicators of good governance in CFUGs are presented below in table 2.

Table 2:Criteria and their respective local indicators of good governance in CFUGs

\begin{tabular}{|l|ll|}
\hline Criteria & & \multicolumn{1}{|c|}{ Indicators } \\
\hline Transparency & (i) & Responsible in setting prices of forest products \\
& (ii) & Record keeping system \\
& (iii) & Punishment and reward transparent \\
(iv) & Satisfied with the existing forest product distribution \\
& & system \\
& (v) & Decision-making \\
& (vi) & Economic and accounting transparency \\
& (vii) & Free access to information regarding decisions, fund, and \\
& (viii) & Know about every decision made \\
& (ix) & Collection, selling and tending transparency \\
& (x) & Overall transparency \\
& (xi) & Implementation of resources \\
& & \\
\hline Accountability & (i) & Accountability of EC towards users \\
& (ii) & Accountability of users towards EC \\
& (iii) & Technical support provided from DFO, if needed \\
& (iv) & Are there any I/NGOs and CBOs supporting the CFUG \\
& (v) & Conflicts over power in the committee and FUG \\
(vi) & The EC members biased to any CFUG members \\
\hline & & \\
&
\end{tabular}

Full text of this article can be downloaded fromwww.craiaj.comand www.nepjol.info 


\begin{tabular}{|c|c|c|}
\hline & $\begin{array}{l}\text { (vii) } \\
\text { (viii) }\end{array}$ & $\begin{array}{l}\text { Rules for CFUG and CFUC meetings } \\
\text { Accountability towards all affected persons and } \\
\text { institutions }\end{array}$ \\
\hline Participation & $\begin{array}{l}\text { (i) } \\
\text { (ii) } \\
\text { (iii) } \\
\text { (v) } \\
\text { (vi) } \\
\text { (vii) } \\
\text { (viii) } \\
\text { (ix) } \\
\text { (x) }\end{array}$ & $\begin{array}{l}\text { Attend in meetings of EC } \\
\text { Attend in meeting of OP/constitution preparation/renew } \\
\text { Attend in meeting of forest product distribution and } \\
\text { collection } \\
\text { Participated in CF activities like monitoring, evaluation } \\
\text { etc. } \\
\text { Participated in training, study tours } \\
\text { Feel free to put your own views at general assembly } \\
\text { Poor/women/DAGs voice taken into account while } \\
\text { making decision } \\
\text { Decision making } \\
\text { Overall benefit sharing } \\
\text { Membership length and renewable status }\end{array}$ \\
\hline Rule of Law & $\begin{array}{l}\text { (i) } \\
\text { (ii) } \\
\text { (iii) } \\
\text { (iv) } \\
\text { (v) } \\
\text { (vi) } \\
\text { (vii) } \\
\text { (viii) } \\
\text { (ix) }\end{array}$ & $\begin{array}{l}\text { Revised and updated constitutions and OP } \\
\text { implementation of OP as per provision made in OP } \\
\text { Proper enforcement of rules and norms of CFUG } \\
\text { Reward and Punishment mentioned in OP and } \\
\text { Constitution and implementation status } \\
\text { Work performance of the CFUC } \\
\text { Evaluation of the policies/objectives of CF management } \\
\text { CF objectives consistent with prevailing forest policies } \\
\text { Status of social discrimination and access to law } \\
\text { Timely recorded system }\end{array}$ \\
\hline $\begin{array}{l}\text { Inclusive and } \\
\text { equity }\end{array}$ & $\begin{array}{l}\text { (i) } \\
\text { (ii) } \\
\text { (iii) }\end{array}$ & $\begin{array}{l}\text { Mode of the benefit sharing } \\
\text { Specific schemes/provisions for poorest people } \\
\text { Uplifting programs such as training and so forth for } \\
\text { female members and minorities }\end{array}$ \\
\hline
\end{tabular}




\begin{tabular}{|c|c|c|}
\hline & $\begin{array}{l}\text { (iv) } \\
\text { (v) }\end{array}$ & $\begin{array}{l}\text { Representation of female, low caste and poor members on } \\
\text { CFUC is according to rules and regulations } \\
\text { Opportunities to all fair and gender balance }\end{array}$ \\
\hline $\begin{array}{l}\text { Effective and } \\
\text { Efficient }\end{array}$ & $\begin{array}{l}\text { (i) } \\
\text { (ii) } \\
\text { (iii) } \\
\text { (iv) } \\
\text { (v) } \\
\text { (vi) } \\
\text { (vii) } \\
\text { (viii) } \\
\text { (ix) } \\
\text { (x) }\end{array}$ & $\begin{array}{l}\text { Forest condition improved or decreased after CF } \\
\text { Deliveries of services to needy people effectively, if } \\
\text { needed } \\
\text { Methods of the forest operations(silvicultural) carried out } \\
\text { Received more forest products than before } \\
\text { Provided forest management training to the users } \\
\text { Forest management activities are carried out in line with } \\
\text { OP } \\
\text { Improvement of bio-diversity and wildlife in CF } \\
\text { Frequency of conflicts related to CF } \\
\text { Preparation of annual plan for implementing the OP } \\
\text { Optimum use of forest resources }\end{array}$ \\
\hline Responsive & $\begin{array}{l}\text { (i) } \\
\text { (ii) } \\
\text { (iii) } \\
\text { (iv) } \\
\text { (v) } \\
\text { (vi) } \\
\text { (vii) }\end{array}$ & $\begin{array}{l}\text { Is EC responsive to your needs? How did they response? } \\
\text { General user's responsive to EC needs } \\
\text { Response to the committee in case your cooperation is } \\
\text { needed } \\
\text { Interact with EC/CFUG members regarding to CF } \\
\text { Participatory and transparent monitoring system } \\
\text { Responsive to quick needs for CF protection } \\
\text { Affected by any decisions of EC/CFUG to local people }\end{array}$ \\
\hline $\begin{array}{l}\text { Consensus- } \\
\text { oriented }\end{array}$ & $\begin{array}{l}\text { (ii) } \\
\text { (iii) }\end{array}$ & $\begin{array}{l}\text { Mode of the decisions at general assembly and EC } \\
\text { meetings on the basis of consensus or majority, } \\
\text { compulsive or spontaneous } \\
\text { Mode of the consensus achieved } \\
\text { How the representatives and leadership positions are } \\
\text { chosen }\end{array}$ \\
\hline
\end{tabular}




\section{Data Collection}

Both primary and secondary data were collected through the different techniques. Primary data were collected through the face-to-face interview in the household survey, key information interviews and focus group discussions. 176 faces-to-face interview with the household head was taken. Total ten focus group discussions was conducted with 10 to 15 persons for each discussion and 8 key information interviews with related stakeholders were taken from field study. Semi-structured questionnaire of elements of governance such as transparency, accountability, participation, inclusiveness and equity, rule of law and effectiveness and efficiency, responsive and consensus oriented, were used for key interviews. A structured and semi-structured questionnaire was used for household survey in order to collect the quantitative as well as qualitative information. Interview in most cases was taken with the household head. In case of the absence of household head, other household members who were familiar with the CF activities were selected for the interview. A questionnaire was initially prepared in English and then translated into the Nepali language before taking the interview of the respondents. For the reliability of the information of the households of CFUGs, pre-testing of the questionnaire was carried out as near area before the household survey. Secondary data were collected from forest management operational plan and constitution, annual audit reports, minutes, correspondence and other records of CFUGs that provided the baseline information about forest resource settings. Collection of blueprints of these CFUGs minutes regarding meetings, assemblies, correspondence and other records such as funds served as a means to cross check the validity of the respondent responses.

\section{Data Processing and Analysis}

Data collected from the primary and secondary sources were in qualitative and quantitative in nature. Collected data were coded and tabulated for further analysis. Data collected from field study for each criterion and their respective indicators were scored in point scale from 1 to 5 . Where the point scale value was assigned as 1 for Strongly Disagree, 2 for Moderate disagrees, 3 for agree, 4 indicate the moderate agree, and 5 used for strongly agree as respondents view in questionnaires and interviews (Dhananjay et al. 2014). The information obtained by some subjective indicators was analyzed logically. Then the coded and tabulated information was initially stored in MS-Excel program and statistical operations such as percentage and mean value were applied to interpret the results. Performance of indicators for each criterion was calculated as below. 
Response of each respondent in each criteria =sum of scores in each criterion $\div$ number of indicators.

Status of each criterion (\%) = sum of response of each respondent in each criterion $\times 100 /$ (expected value $\times$ numbers of respondents). And Status of governance in each CFUG (\%) $=$ sum of the status of each criterion $(\%) /$ number of criterion.

Finally, the overall performance is estimated by weighted average of percentage (\%) score of individual criterion. The estimating score for individual criterion is helpful to identify the areas for improvement in the future. The calculated result was then interpreted in tabular form, bar charts, matrix ranking wave and graphical forms. For further analysis the performance score \% obtained from above calculation was compared with the performance measurement scale suggested by the Urban Government Initiative of Malaysia for Forestry sector governance as below.

Table 3:Performance measurement scale suggested by the Urban Government Initiative of Malaysia

\begin{tabular}{|l|l|}
\hline Score Range (\%) & Condition Remarks \\
\hline $85-100$ & Very good Keep it up \\
\hline $65-84$ & Good still room for improvement \\
\hline $50-64$ & Medium still plenty of rooms for improvement \\
\hline $35-49$ & Poor needs more efforts and commitment to improve \\
\hline Below 35 & Very poor needs major reforms to improve \\
\hline
\end{tabular}

\section{Results and Discussion}

The performances of each indicator were analyzed based on the scoring as discussed above. The overall status of good governance for each CFUG was shown in figure below. The total performance of governance status in each CFUGs level was obtained highest score $85 \%$ and lowest score $68.8 \%$. The analysis of all eight criteria as shown in the overall highest score was assigned for transparency $82 \%$ and the lowest score was $74.1 \%$ for participation in the study area. This means that, the participation of users in executive committee and other activities of CF were not enough as they wish. However, executive committee of CFUGs was formed as per their constitution by obeying forest act and regulation, Yadav et al., 2017 shows that the people near to local politics and 
economically strong frequently influence the decision making process of CFUGs at local level. Many literatures, (Luintel et al., 2017; Pant, 2017; Chhetri et al., 2016; Suwarno et al., 2015; Lamichhane and Parajuli, 2014; Thakur, 2011)show the comparatively good status of governance in community forests in different parts of Nepal. However the issues related to accountability of executive committee to all users and economic transparency shows the either medium or poor values (less than 64\%) (Baral and Stern, 2011). Here in this study found transparency in CFUGs was highest because of regular monitoring by supportive agencies, government officials and low economic activities of their CF.

Figure 1: Matrix wave shows the values of governance indicators

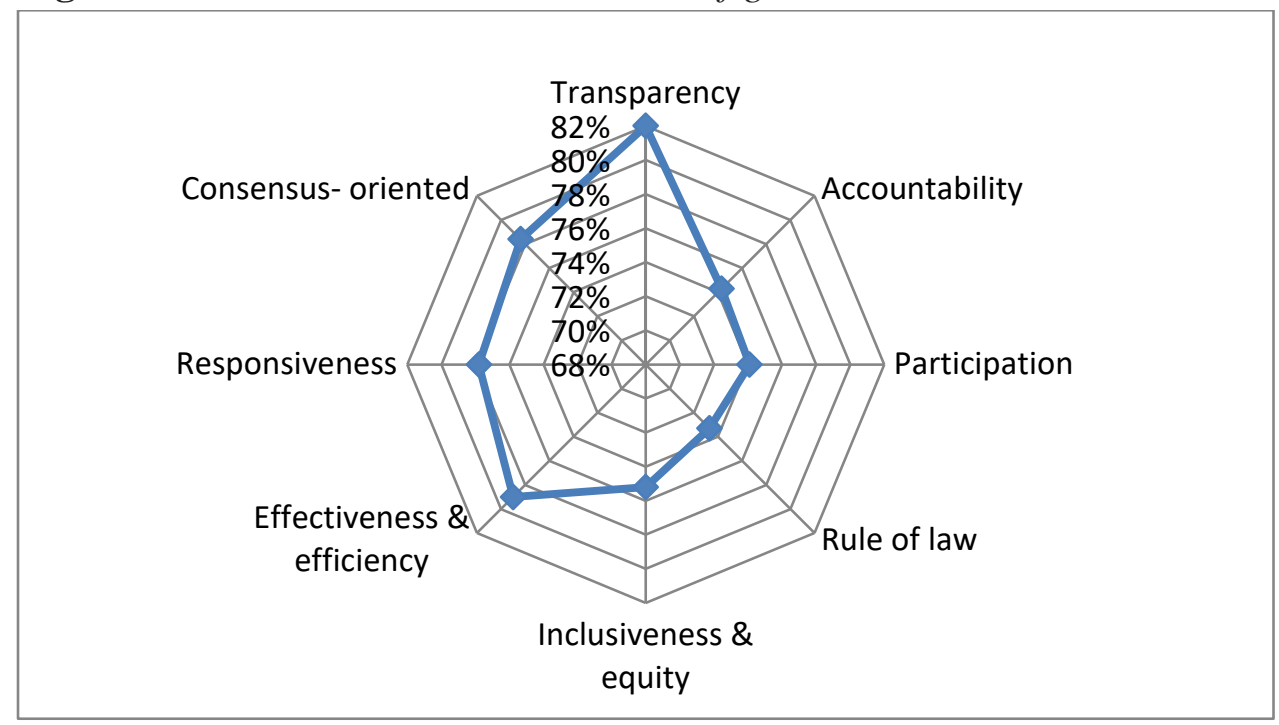

Further research in this area Shrestha and Shrestha (2017); (Lawler and Bullock, 2017; Giri, 2006) shows the medium level governance and low level of active participation of marginalized communities in decision making process in community forestry level in central Nepal. Past studies Thakur (2011) and Yadav et al. (2017) highlight that most of the CFUGs are captured by wealthier and upper caste male people of local level and therefore, the voices and concerns of the dalits, poor and women, disadvantaged groups, who depend more on forest resources for their livelihoods are not adequately taken into account in CF process however the status of governance shows the good status. 
Giri and Ojha (2011) and Gurung et al. (2013) show that the trend of inclusion of women, dalits, janjati and other marginalized groups in leadership position of executive committee has increased over each year. More interestingly, dalits leadership position has been increased at rate of $6 \%$ per year in the period of 2000 to 2008, while that of janjati have increased at a rate of 1.5\% (Brown, 2012). However, challenging still remaining there to include socially and economically deprived people in the major leading positions (Watkins et al., 2012). This study also agreed that the participation of minorities in EC is increased but empowerment enhancement related supports are required in the future for such minorities and target groups. According to the Persha and Andersson (2014) and Yadav et al. (2017) the power of decision- making is an important consideration given the criticism often made of CFUGs \& CFUCs, that they are often captured by local elites.

Government of Nepal implemented different policies and guidelines to manage community forestry and to improve status of governance. But, benefit sharing in resource distribution, continue conflict between the CFUGs and department of forest and inclusion of targeted groups in decision -making process and influence of local elites are some of broader challenges for good governance in CF program in Nepal (Poudel et al., 2015; Lacuna-Richman et al., 2016; Cadman et al., 2016; Bhatta et al., 2014; Maharjan et al., 2004). This study not only highlights the above issues of good governance but also lack of knowledge for conservation strategies and decreasing pattern of forest product to users need is a major issue for governance which divert the general people interest from forest management to alternative strategies. Maharjan et al. (2004) and Acharya (2017) refer that, to address the issues in CF as weak institutional capacity of CFUGs, inadequate service delivery, lack of equal access to information and lack of capacity and skills for practicing good governance at all level are challenging issues. This study strongly agrees that lack of capacity and skills are key challenges for practicing good governance in community level.

According to (J. Adhikari, 2013) the transparency of resource allocation procedures, incentives for central authorities to develop powers, community engagement and good governance are key factors that influence the institutional arrangements for governing forests and other resources. Exclusion in Executive Committee, low participation of disadvantaged and marginalized groups in EC and inequality in benefit sharing between different social groups in CFUGs are challenging issues for good governance in forestry sector (Yadav et al., 2017) and (Paudyal, 2017). The second 
generation issues such as livelihood contributions, Sustainable Forest Management (SFM), and good governance has emerged recently in CF (Luintel et al., 2017). This study also found that the economically poor and non-timber sailing CFUGs are comparatively more transparent than timber selling and economically strong CFUGs.

Sullivan (2016) state that the major challenges in CF are lack full empowerment of women and disadvantaged groups and the success are not uniform throughout the country. With the devolution in CF, there is a misuse of power by local elites and there is a potential for either genuine local empowerment or abuse of new source of power by elite group (Nelson and Wright, 1995). It was found that majority of EC members of CFUGs from minority and disadvantaged category had lack of Knowledge of policy and operation plan of their CF. this shows the empowerment is necessary for good governance in community forestry. Due to the success in conservation and greenery development, CF is highly touted as the successful participatory model in Nepal (Giri and Ojha, 2011). But, at the same time the second generation issues like good governance, sustainability as well as later types of output are equally prevalence, so that participatory exclusion, centralized decentralization, lack of equity and fairness, poor transparency (Paudyal, 2017) has emerged as higher challenges due to the lack of perfectly good forest governance. Plans and policies of CF are developed in such a way that increases democratization and equitable access to forest products for the marginalized group, poor and disadvantaged group. And the CFUGs are all inclusive, executive committee will represent the various interests groups in the community, rules and regulations are equal for all users and all users will have an equal share in the benefit of forest. But, there are few studies, however, which clearly demonstrate that, most user groups are exclusive in terms of participation and benefit sharing from CF (Lamichhane and Parajuli, 2009; Thakur, 2011; Gurung et al., 2013).

Making CFUGs more transparent and more accountable towards their responsibility government and other non- governmental agencies are supporting to the CFUGs and Community Forestry User Committee (CFUC) about financial resources management, planning and implementation of CF programs in transparent way, and leadership development trainings for target groups. Level of education and awareness about good governance was very poor in the respondents of study area. However they were benefited from the different trainings and awareness programs conducted by the supportive agencies. In this study the accountability of CFUC to their users was founded to higher in

Full text of this article can be downloaded fromwww.craiaj.comand www.nepjol.info 
small CF and in the community where majority of same ethnic groups in the society. In the same time governance status is very high in the economically poor CF than others. The free access of information for all users was also found very high in non- timber selling CF than timber selling CF. in timber selling CF, the free access of all information for users was found average level. In the study of the six CFUGs, of Far- western Terai region of Nepal the percentage score of overall status of governance is $76.3 \%$. This shows good governance but still needs some improvements to make it very good.

\section{Conclusion}

The main objective of this research was to identify and analyze the status of good governance in CFUGs with the help of eight criteria of good governance and their respective local indicators. Both primary and secondary data were collected and analyzed. Qualitative data were analyzed through logically and quantitative data were analyzed using statistical methods. This study concludes that overall status of governance is good but still needs improvements in different indicators. The governance of community forest is affected by the activities of CF and its economic status. In general all CFUGs have constitution with specific provision for participatory management committee. However the vital posts of ECs are influenced by local power holders. Lack of education and awareness about the role and responsibility users in forest management may be reduced by the help of empowering the communities. From the above results and discussion about good governance in CF, it is clear that the overall status of good governance in CF was good and requiring few improvements in their activities.

\section{Acknowledgements}

I am grateful to those valuable respondents who expressed their views and provide valuable time at the field study. I express my grateful and sincere thanks to the Dr. Rashila Desar and Terai Arc Landscape (TAL)-Bottle necked and restoration project grant no. $\mathrm{T}$ 114, Kohalpur, Nepal for providing fund for this research.

\section{References}

Acharya, K. (2016). Impaired governance: Limiting communities' access to service delivery system in Nepal. Himalayan Journal of Sociology and Anthropology, 7, 40-74. $\quad$ https://doi.org/10.3126/hjsa.v7i0.17150 
Baral, N., \& Stern, M. J. (2011). A comparative study of two community-based conservation models in Nepal. Biodiversity and Conservation, 20(11), 2407-2426.

Bhatta, L. D., van Oort, B. E. H., Rucevska, I., \& Baral, H. (2014). Payment for ecosystem services: possible instrument for managing ecosystem services in Nepal. International Journal of Biodiversity Science, Ecosystem Services \& Management, 10(4), 289-299, https://doi.org/10.1080/21513732.2014.973908

Cadman, T., Maraseni, T., Breakey, H., López-Casero, F., \& Ma, H. O. (2016). Governance values in the climate change regime: Stakeholder perceptions of REDD+ legitimacy at the national level. Forests, 7(10), 212. https://doi.org/10.3390/f7100212

DoF (2017). Community forest user groups data base record, Available in Managenment Information System Kathmandu, Nepal: Government of Nepal, Department of Forests.

Gautam, A. P. (2009). Equity and livelihoods in Nepal's community forestry. International Journal of Social Forestry, 2(2), 101-122.

Giri, K. (2006, November). Resource complexities and governance mechanisms: Evaluating community forestry program of Nepal. In Presentation held at the Conference on Human Dimensions of Global Environmental Change, Berlin, Germany (pp. 17-18).

Giri, K., \& Ojha, H. R. (2011). How does techno bureaucracy impede livelihood innovations in Community Forestry. Kathmandu, Nepal: Forest Action.

Gurung, A., Bista, R., Karki, R., Shrestha, S., Uprety, D., \& Oh, S. E. (2013). Communitybased forest management and its role in improving forest conditions in Nepal. Small-Scale Forestry, 12(3), 377-388.

Graham, J., Amos, B., \&Plumptre, T. W. (2003). Governance principles for protected areas in the 21st century (pp. 1-2). Ottawa: Institute on Governance, Governance Principles for Protected Areas.

Lawler, J. H., \& Bullock, R. C. (2017). A case for Indigenous community forestry. Journal of Forestry, 115(2), 117-125. https://doi.org/10.5849/jof.16-038

Lamichhane, D., \& Parajuli, R. (2009). Status of Good Governance in Community Forestry: A Study from Gorkha District. Tribhuvan University, Institute of Forestry.

Lamichhane, D., \& Parajuli, R. (2014). How good is the governance status in community forestry? A case study from midhills in Nepal. Journal of Ecosystems, 2014.

Full text of this article can be downloaded fromwww.craiaj.comand www.nepjol.info 
Maharjan, M. R., Acharya, B., Lamichhane, R. P., Sharma, N. N., Pradhan, B. R., \& Paudel, T. P. (2004). Operationalisation of good governance in community forestry: an experience from SAGUN programme. Twenty-five years of Community Forestry: Contribution in Millennium Development Goal, 4-6.

Nelson, N., \& Wright, S. (1995). Power and participatory development: Theory and practice. ITDG Publishing. http://research.gold.ac.uk/id/eprint/11803

Paudyal, K. (2017). Assessment of policy issues for biodiversity conservation at buffer zone of Royal Chitwan National Park, Nepal. Banko janakari, 11(1), 9-15.

Poudel, M., Thwaites, R., Race, D., \& Dahal, G. R. (2015). Social equity and livelihood implications of REDD+ in rural communities-a case study from Nepal. International Journal of the Commons, 9(1). http://doi.org/10.18352/ijc.444

Quibria, M. G. (2015). Governance in developing Asia: concepts, measurements, determinants and a paradox. In Governance in Developing Asia. Edward Elgar Publishing.

Shrestha, S., \& Shrestha, U. B. (2017). Beyond money: Does REDD+ payment enhance household's participation in forest governance and management in Nepal's community forests? Forest Policy and economics, 80, 63-70. https://doi.org/10.1016/j.forpol.2017.03.005

Thakur, R. B. (2011). Status of Governance in Community Forest Users Group (CFUGs) of Nepal: A Case Study from CFUGs of Surkhet District (Doctoral dissertation, TERI) University).

Yadav, B.D., Bigsby, H., \& MacDonald, I. (2017). Rules of benefit distribution: A dynamic impact on Nepalese community forestry organizations. Journal of Sustainable Forestry, 36(2), 177-197, https://doi.org/10.1080/10549811.2016.1275700

Full text of this article can be downloaded fromwww.craiaj.comand www.nepjol.info 